DOI: https://doi.org/10.15407/kvt205.03.026

UDC: 004.9:911.5/.9:528.94

CHABANIUK V.S. ${ }^{\mathbf{1 ,},}$, PhD (Phys.-Math.),

Senior Researcher of the Cartography Department, Institute of Geography, Director of "Intelligence systems-GEO" LLC,

ORCID: 0000-0002-4731-7895

email: chab3@i.ua,chab@isgeo.kiev.ua.

KOLIMASOV I.M. ${ }^{2}$,

Head of Production of "Intelligence systems-GEO" LLC,

ORCID: 0000-0002-4927-4200

email: kolimasov@ukr.net.

${ }^{1}$ Institute of Geography, National Academy of Sciences of Ukraine

44, Volodymyrska str., 01054, Kyiv, Ukraine

2 "Intelligence systems-GEO" LLC,

6/44, Mykilsko-Slobidska str., 02002, Kyiv, Ukraine

\title{
CRITICAL SYSTEMIC PROPERTIES OF ELECTRONIC ATLASES NEW GENERATION. PART 2: RESEARCH RESULTS
}

Introduction. Part 2 discusses three critical systemic properties (CSP) of Electronic atlases (EA) new generation. With their help are determined fundamentally new, systemic EA. Compared with classic systems, new EA have much more opportunities to model spatial systems of actuality.

The purpose of the paper is to describe and to prove the criticality of three CSP for a new generation of EA - systemic EA.

Results. Three CSP are described: CSP1.System, CSP2.Tree, CSP3.View. CSP1.System means that systemic EA should be models of spatial systems of actuality. These models are primary in contrast to the classic EA models, which are secondary. CSP2.Tree means that the contents/solutions tree of the systemic EA must classify the modeled spatial system of actuality. CSP3.View should model the visualization needs of users, in particular through interactivity. The methods of Conceptual Frameworks and Solutions Frameworks of Relational cartography, as well as facts from Model-Based Engineering were used for proof.

Conclusions. Three CSP of systemic EAs are described and it is proved that each of them is a necessary property of EA new generation.

Keywords: Electronic atlases new generation, critical systemic property, Conceptual Framework, Solutions Framework, Relational cartography.

(c) CHABANIUK V.S., KOLIMASOV I.M., 2021 


\section{INTRODUCTION}

Part 2 takes into account the content of Part 1 [1] two main sections. The first presents the evolution of Electronic atlases (EA) over more than four decades: from the mid-1980s to our time. It is argued that in our time the evolution of EA leads to a revision of the cartographic and systemic foundations of EA until their revolutionary changes. The authors suppose that revolutionary changes should be considered in the context of a fundamentally new EA class, named Systemic (SEA). In general, the problem both Parts 1 and 2 of this article is formulated in the first main section of Part 1.

Part 1 second main section describes research methods. They are architectural patterns, which in computer science are called frameworks. The first is named the Conceptual Frameworks (CoFr) method valid for the Spatial Information Systems (SpIS) of the defined classes. This fact is proved for the SpIS, which are EA or, more generally, AtS = EAAtIS (AtIS - Atlas information system). CoFr determines, in a fixed period of information technologies stability, the structure of defined SpIS (for example, EA) in the so-called broader sense (SpISb). SpISb include the SpIS of end users also named the systems in the narrow sense - SpISn. And also all models of SpIS (SpISn) which exist both at phases of its development and operation. Some of them are created physically. As a method, CoFr provides the interaction between the SpS of actuality and the SpISb. In particular, this method is designed to transform MEA (modern EA) into SEA. It is used to identify the first critical systemic property (CSP1) - CSP1.System.

The second is named the Solutions Frameworks (SoFr) method. There are several SoFr for each $\mathrm{CoFr}$, as SoFr provide interaction between the knowledge about the SpISb (components) of users who belong to neighboring "echelons". There are four echelons in each particular Formation. Formation is associated with a period of stability of information technologies in the atlas context. CoFr of some SpISb for each Formation identifies four echelons of users who must have knowledge of the respective four strata of the system. Examples of adjacent echelons are Operational and Application, which in SpISb correspond to strata with similar names. The Operational is the echelon of end users. The Application is mainly the echelon of developers. AtlasSF1.0 SoFr mentioned below is used between Application and Operational echelons of users or between components (elements, systems) of the corresponding EAb (SpISb) strata. SoFr is more specific than CoFr. This specificity is determined by: 1) the strata between which SoFr is used, 2) the solution components, to which SoFr is applied. In this work the SoFr method is used to identify two CSPs: CSP2.Tree (solutions/contents tree) and CSP3.View (view). The second section of Part 1 is finished by the explaination why $\mathrm{CoFr}$ and $\mathrm{SoFr}$ can be used in conjunction with Model-Based Engineering (MBE).

The main sections of Part 2 from the first to the third consider three critical systemic properties (CSP). They are easier to explain with CoFr. The first CSP (CSP1) is determined by the relations between the modeling system SEAb and the corresponding modeled system SpS of actuality. The second CSP (CSP2) is determined by the classification relation of subject area by using the $\mathrm{CoFr}$ Datalogics of such SEAb construction as a solutions/contents tree. The third CSP (CSP3) is determined by the relations between the hierarchical knowledge of the users of the Operational and Application echelons and the corresponding 
SEAb views. It is easy to see that CSP1 refers to SEA (SEAb) as a system in a whole, CSP2 refers to SEA (SEAb) Datalogics of a two-dimensional system second "dimension", and CSP3 also refers to SEA (SEAb) Uselogics of a twodimensional system second "dimension".

The first section of Part 2 uses the CoFr method to identify the first, and main, critical systemic property of SEA - CSP1, which is called CSP1.System. CSP1.System - SEA must model the Spatial systems (SpS) of actuality.

Germany (Europe) autobahns Atlas is used as the SEA example. This Atlas has both paper and electronic variants. Its de facto used to interpret the MBE concepts in (Kühne, 2006) [2]. We used Kühne\&apos;s inferences and extended them to the representation of the Germany autobahns Atlas in accordance with the SEA CoFr.

The second section of Part 2 uses the AtlasSF SoFr method to describe CSP2, which is called CSP2.Tree and consists of three interrelated CSPs:

- CSP2.Tree.DA - Datalogics of the solutions tree is a critical systemic property.

- CSP2.Tree.DA-DO - The rigid relation between the Datalogics of contents and solutions trees (Operational and Application strata) is a critical systemic property.

- CSP2.Tree.DO - Datalogics of the contents tree is a critical systemic property.

Simply speaking, CSP2. Tree argues that the SEA should classify the subject area. For this classification, it is sufficient to perform data classifications for the SEA application, i.e., for the component models and/or systems of the SEA CoFr Operational and Application strata. This Datalogical Epistemological classification can be called ontological according to [2]. The ontological (or Datalogical Epistemological) classification is responsible for the epistemological relations between the contents and solutions trees. This classification is well known in IT. It\&apos;s called instanceOf (instanceOfSomething) or classification. The inverse relation is called instantiation (exemplarisation).

The third section of Part 2 discusses CSP3, which is called CSP3.View and consists of two interrelated CSP: session.

- CSP3.View.State - Preservation of several SEA states in the operation

- CSP3.View.Interaction - Interactive view of SEA to users with different qualifications.

The information in this section is very important to explain the SEA\&apos; $\mathrm{s}$ relation to the "live" world of users. It uses maps interactivity, which on the one hand is a substantive feature of modern electronic maps, and on the other hand, more importantly, it represents the views of users of the respective groups on atlas maps and the atlas as a whole. Maps interactivity has been extended to atlas interactivity and its place in AtlasSF is shown. It uses a view pattern, which is a logical combination of views of the main components of the SEA and/or AtlasSF.

The "Conclusions" section provides the conclusions of Part 2. 


\section{RELATIONS BETWEEN SEA AND SPS OF ACTUALITY: CSP1.SYSTEM}

The most important, the first SEA critical systemic property CSP.System, is formulated as follows:

- CSP1.System - SEA must model the spatial systems (SpS) of actuality. It implies that SEA should not be just collections or sets of pre-created maps (to be a secondary model of actuality), but be a model of actual system (to be a primary model of actuality). Examples of such systems/models are Classic dynamic atlas systems and Atlas geographic information systems (AGIS) [3].

Geographic (spatial) system (geo-system (spa-system, $\mathrm{SpS})$ ) is an ordered pair (A, R), where A is a set of things (entities), among which are geographic (spatial), and $\mathrm{R}$ is a set of relations between things (entities) of the set $\mathrm{A}$, which form a unity or organic whole. The term 'geo-system' is left to synchronize with the physical geography and topography that studies the Earth's surface. The concept of 'relations' is understood as in systemology. There it includes the whole set of related concepts, such as constraint, structure, information, organization, cohesion, interaction, coupling, linkage, interconnection, dependence, correlation, pattern etc [4].

Somebody may disagree with the criticality of CSP1.System, because it depends on how the researcher understands the concept of "system". For example, B. Gaines [5; p. 1] uses the following definition: "A system is what differs as a system". That is, the system by this definition can be everything. At first glance, it seems like an unnecessary statement. However, then B. Gaines argues that this definition of the system is meaningful and rich in systems theory. In particular, he argues that "In this lies the essence of systems theory: that to distinguish some entity as being a system is a necessary and sufficient criterion for its being a system, and this is uniquely true for systems. Whereas to distinguish some phenomenon (entityies) entity as being anything else is a necessary criterion to its being that something but not a sufficient one" (ib.; p. 2).

This work does not consider the relations between "information" EAb or SEA and "general" EAb or SEA. Note in passing that the "information" EAb here means a subset of SpISb, which is shown in [1; Fig. 2] on the example of EINAUb. "Information" SEA are also a subset of SpIS, although this is not shown in [1; Fig. 2]. "General" EAb are the subset of the General SpS, as shown in [1; Fig. 2] on the example of General NAUb. "General" SEA is also a subset of the General SpS, although this is not shown in [1; Fig. 2]. Among the relations between "information" and "general" SEA are also critical, which are especially important in the design of SEA. However, for the actual introduction into the SEA issue, we need simpler, "non general system" CSP. CSP.View is such an example.

Consideration of CSP1.System will begin with the fact that the modeled systems of actuality should be not arbitrary systems, but spatial systems $(\mathrm{SpS})$ of (or "on") the Earth. Their perception, in contrast to arbitrary systems, is not so arbitrary, because the concept of "space" in "earth" systems has both scientific and universal interpretations. Among modern scientific interpretations, we hold the view that in reality it is possible and necessary to distinguish "Relational space - the viewpoint of space as a product of relations between entities (objects). Space in this viewpoint arises at the same time as the entities (objects) in it, which contrasts with absolute 
space" [6; p. 280]. In our constructions, relational space is associated primarily with the concrete space of A. Aslanikashvili [7].

Between T. Cresswell and A. Aslanikakshvili works is almost 40 years apart, but so far the question of the inquiry domain (research subject, subject domain, cognition or research subject) of modern cartography and the related definition of cartography has not been resolved. This issue is particularly acute for the SEA (EA/AtIS). Thus, the International cartographic association (ICA) still cannot change the definition of cartography to a more modern one. To be able to respond to modern challenges to cartography in the monograph [8; p. 9] the definition of the latter is changed as follows:

- Classic (or Subject) cartography - the arts, sciences and technologies of making and using maps. This is a slightly modified definition from [9]. A. Aslanikashvili criticized such definitions and therefore put forward his understanding of the subject of cartography. We agree with his thoughts and from our part introduced the concept of two-dimensional system cartography, determining the first dimension as subject cartography, and the second dimension as relational cartography.

- Relational cartography (RelCa) - coordinated arts, sciences and technologies of making and using relations in cartographic systems and between cartographic systems.

- (System(ic) or Geomatic or simple) cartography - coordinated and uncoordinated arts, sciences and technologies of making and using maps, cartographic relations and cartographic systems.

We can not be tolerant in the definition of cartography by ICA, because according to this classic definition, neither modern electronic atlases, nor modern atlas information systems, nor their domains are not in fact the subject of knowledge (research) of (modern) cartography. On the other hand, it is quite difficult to name the fields of science that would be concerned with SEA (EA/AtIS). It is assumed that the domains of SEA (EA/AtIS) could be attributed to the inquiry domains of CIS or GIS. However, there are some problems that are not addressed in this article.

Below we have described two variants of the SEA relations with spatial systems of actuality: simpler and more complicated. In the simpler variant, the CoFr method is essentially not used. It is almost entirely proved using facts from Model-Based Engineering (MBE, see for a start [10]). In a more complicated variant, in addition to MBE, CoFr and the theory of Relational cartography are also significantly used [8].

Simpler variant. The relations of SEA with actuality systems are explained in Fig. 1. This figure is obtained by the logical combination of the Physical World and the Application and Operational strata of CoFr EAb (EINAUb) [1; Fig. 2] with "Fig. 2 Kinds of model roles" [2]. [1; Fig. 2], in turn, is logically aligned with "Fig. 6 Linguistic metamodels" [2]. We did not complicate the figure by showing the correspondence between the CoFr elements and the language (linguistic) elements shown on the right in Fig. 1. In Fig. 1 marked:

- token modelOf: Holds between a system and a model, representing the system in a one-to-one fashion (one system corresponds to one model); model elements can be considered as determinants of system elements,

- type modelOf: Holds between a system and a model, classifying the system in a multi-to-one way (many systems correspond to one model); model elements can be considered as classifiers of system elements, 


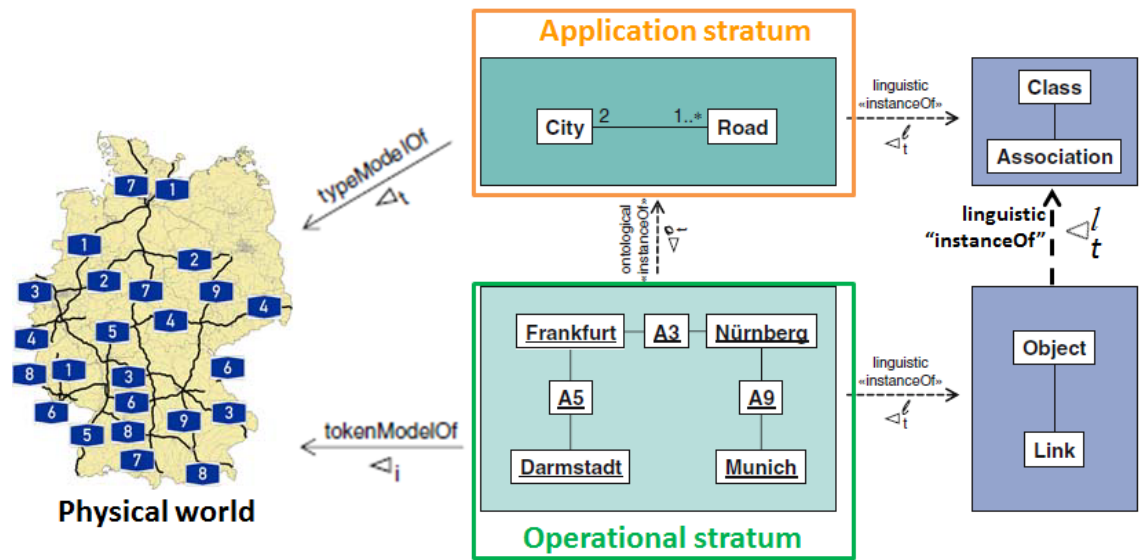

Fig. 1. The relation between the actual $\mathrm{SpS}$ of the physical world and the EINAUb Application and Operational strata. Used (Kühne, 2006) [1; Fig. 2, Fig. 6]

- instanceOf relation was used by us to denote the bottom-up relations between the elements of two adjacent strata. Use of this relation in practice is called classification. The reverse use is called instantiation or exemplification. Fig. 1 shows two classifications: ontological and language. So far, we have used the generalized terms "epistemological" to denote the relations between the elements of the strata in the bottom-up direction and "reduction" to denote the relations in the top-down direction. Recall the definition of ontology and epistemology. "Ontology (from the greek. on — genus n. ontos — being and ... logy) - a section of philosophy, the doctrine of existence (as opposed to epistemology - the doctrine of cognition), which explores the general basics, principles of existence, its structure and regularities; the term was introduced by the german philosopher R. Goklenius (1613)" (LED, 1993; p. 933) [11 p. 933]. "Theory of cognition (epistemology) - a section of philosophy, which studies the regularity and possibilities of cognition, the relations of knowledge (feelings, ideas, concepts) to objective reality, explores the degrees and forms of the process of cognition, conditions and criteria of its reliability and truth. Summarizing the methods and techniques used by modern science (experiment, modeling, analysis and synthesis, etc.), the theory of cognition acts as its philosophical-methodological basis" (LED, 1993; p. 1321) [11; p. 1321].

Recall the definition of ontology and epistemology: "ontology: a particular theory about the nature of being or the kinds of things that have existence", "epistemology: the study or a theory of the nature and grounds of knowledge especially with reference to its limits and validity" [11].

These definitions allow us to conclude that ontological relations should be given in an actual real spatial system, and in a modeling spatial system these relations should be called epistemological. Therefore, in our work we use the term "epistemological" relations instead of the term "ontological" relations in (Kühne, 2006) [1]. That is, instead of "ontological instanceOf" in Fig. 1 "epistemological instanceOf" should be used in our constructions. For Web 1.0 Atlases, the bottom-up relations ("epistemological instanceOf") between the elements of the Application and Operation strata is called "classification". The inverse relationship is called "instantiation". 
However, the "linguistic" relations between the elements of the strata are also called by us and are in fact epistemological. Therefore, for example, instead of "linguistic instanceOf" between vertical elements belonging to adjacent strata (Fig. 1) it is possible to use epistemological "instanceOf". In this article, we went further and divided the epistemological relations into three groups, using three levels of the Conceptual framework: Datalogical (or Technological context), Infological (or Language (Linguistic) context) and Organizational (or Usage context). The epistemological relations between the Datalogical components are called the Datalogical Epistemological relations and they coincide with the Ontological relations in (Kühne, 2006) [2]. Epistemological relations between Infological components are called Infological Epistemological relations and they include linguistic instanceOf (Kühne, 2006) [2]. Finally, the Epistemological relations between Organizational components is called the Organizational Epistemological relations and they include both the relations between the elements of the system and the relations between user knowledge.

In [2] the Germany autobahns network is used as an example of an actual spatial system of the physical world. The model of each autobahn is denoted by An (Autobahn n), where $\mathrm{n}=3,5$, 9 within Fig. 1. To represent this spatial system in Fig. 1, apparently used "landkarte deutschland (autobahnnetz) / map of germany (street map)" from [12]. Although it may be a map from [13].,

If you take a closer look, it turns out that in [2] the model of the Germany autobahns network is supplemented with a representation of the cities through which individual autobahns pass. Representation without cities is shown in Fig. 2.

It turns out that cities appear only in the model in Fig. 1 (in the middle, Operational and Application strata). For a better understanding of the Germany autobahns network, we use a representation of the required system [15] on the Google map (Fig. 3).

Google Maps uses almost the same autobahn notations from the maps above. Therefore, thanks to Google Maps, the interested reader can get a fully available online idea of the actual spatial system of the physical world being research.

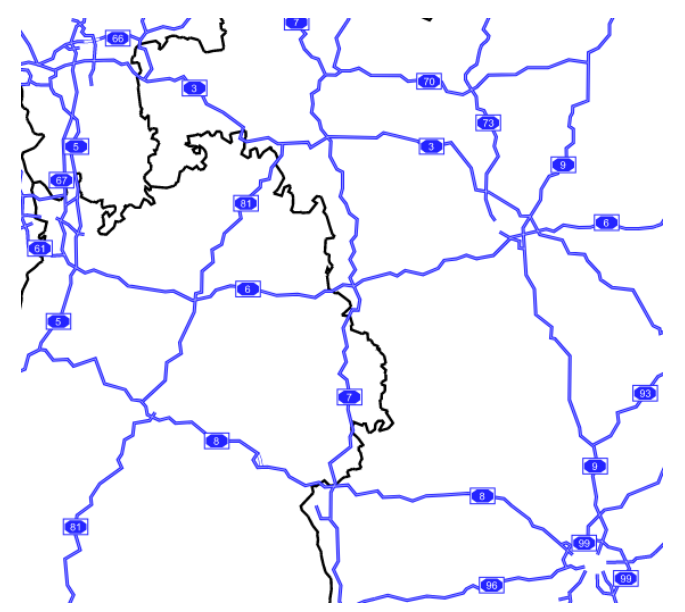

Fig. 2. Representation of the part of the Germany autobahns (highways) we need from the website [14]. Cities not shown 


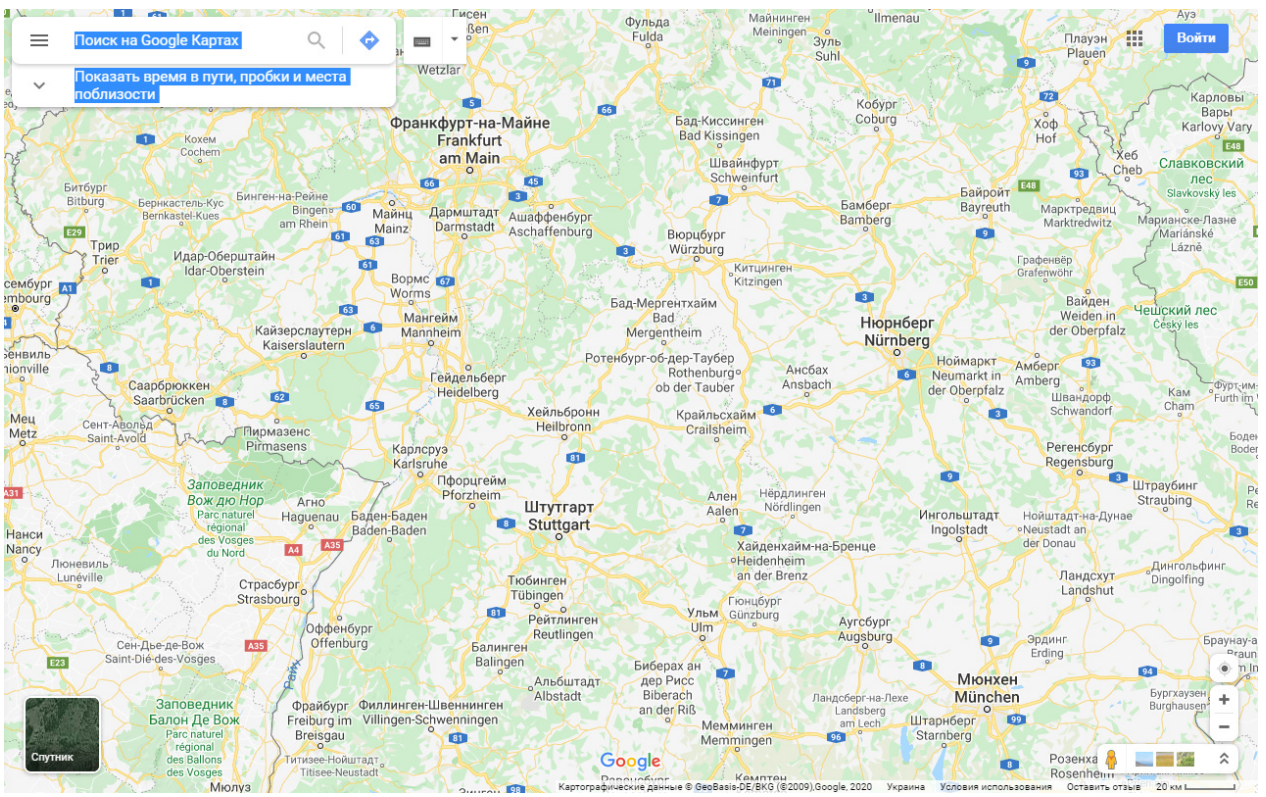

Fig. 3. Representation of the actual $\mathrm{SpS}$ of the physical world from Fig. 1 on the Google map

To bring this example as close as possible to the topic of this article, we can say that T. Kühne [2] could even consider the actual $\mathrm{SpS}$ of the Germany autobahns, which is modeled by the Germany autobahns atlas. It is clear that the actual $\mathrm{SpS}$ for this atlas is somewhat more complex than shown in the previous figures. However, the main things (entities) in this system are settlements, and the main relations between them are fragments of autobahns

Fig. 1 shows two models of actual SpS: language (linguistic) and ontological. The language model is perceived by us as a highways paper atlas, which usually consists of sheets of a book. The user must find a (paper) sheet with the highways that interest him at the moment. Finding this sheet corresponds to moving on the base map of the atlas.

In contrast to the language model, the ontological model allows us to first find the value of the entity or relation that interests us, and only then perform positioning on the desired base map. Obviously, such operations are best performed with an electronic version of the atlas.

In Fig. 1 under the map of Germany autobahns the "Physical world" is signed. In this case, it means that the map only represents part of the actual SpS and is not this system. The language model of a part of the actual $\mathrm{SpS}$ is referred to the CoFr Operational stratum, and the ontological one is referred to the $\mathrm{CoFr}$ Application stratum. This is because both models are also representations, only in this case of the specific EA/AtIS of the Operational stratum and its class of the Application stratum, respectively. The electronic implementation of the language model is EA/AtIS of the Operational stratum. For example, in the case of the National atlas of Ukraine project, it was the Electronic version of the National atlas of Ukraine on DVD (EINAU2007/2010). This atlas did not allow editing, but an editable version of the same atlas was created on the Application stratum, which was called EINAU_Edited. In essence, EINAU2007/2010 was a 
language model of the actual $\mathrm{SpS}$ of Ukraine, and EINAU_Edited was an ontological model of the actual $\mathrm{SpS}$ of Ukraine

At the end of this paragraph, we draw readers attention to the clear presence in the actual spatial system of the physically existing relations "autobahn" and "at least one autobahn passes through the city". This example shows the fundamental difference between atlases as a collection of maps and atlases as a system. A collection (set) of maps can be created by collecting maps that are made without paying attention to systemic issues. If the researcher is based on classic cartography, then the most important thing for him is a separate map usually a model of a field of the same type entities of actuality. Then other fields are modeled in the same way. After that, the created maps are collected in a collection of maps and the result is called an atlas. It turns out that this collection is unlikely to be a modern atlas.

Interestingly, this collection will not be an atlas, even from the classic viewpoint, which is set out in the monographs [16], [17], [18]. After all, in the definition of the geographic atlas by K. Salishchev there is such a phrase: "performed according to the general program" $[17 ;$ p. 185]. Thanks to the Conceptual framework, we now know that the "general program" of creating an atlas is an element of the Conceptual stratum, which is closely related to the elements of the Application stratum and, through them, to the elements of the Operational stratum. Let's recall about the epistemological relations between the elements of strata, which primarily materialize knowledge between the elements.

More complicated variant. Our interpretation of some picture elements of [2] on Fig. 1 is not entirely accurate, namely:

1. The ontological model in UML terminology is called a class diagram, which is the result of the conceptual design stage of the AtIS development phase. It is quite obvious that the class diagram does not model the $\mathrm{SpS}$ of the physical world, but in the terminology of CoFr - the abstract-physical world.

2. The language model in UML terminology can be called an object diagram, which is also the result of the conceptual design stage of the AtIS development phase. Like the class diagram, the object diagram does not model the SpS of the physical world, but in the terminology of the CoFr, the abstractphysical world.

3. Fig. 2 of [2] will be accurate provided that the author meant the map of Germany autobahns, which is then modeled on UML. Therefore, to prevent inaccuracies in interpretation to represent actuality, we use satellite images. For a more accurate representation of the Germany autobahns network, it is possible to use Google images Fig. 4 [19].

Taking into account the above, as well as using the CoFr method, the specified part of Fig. 1 looks like in Fig. 5.

As a paper map of autobahns in Fig. 5 used a map of the territory we need from a paper atlas of European highways. We will not specify the concept of "Cartographic image" in Fig. 5. These can be Ontological and Language (Linguistic) models of the map from Fig. 1, but not required. Here we pay attention to the existence of two types of relations between the Conceptual stratum and the Abstract world, as well as the Abstract-physical world. 


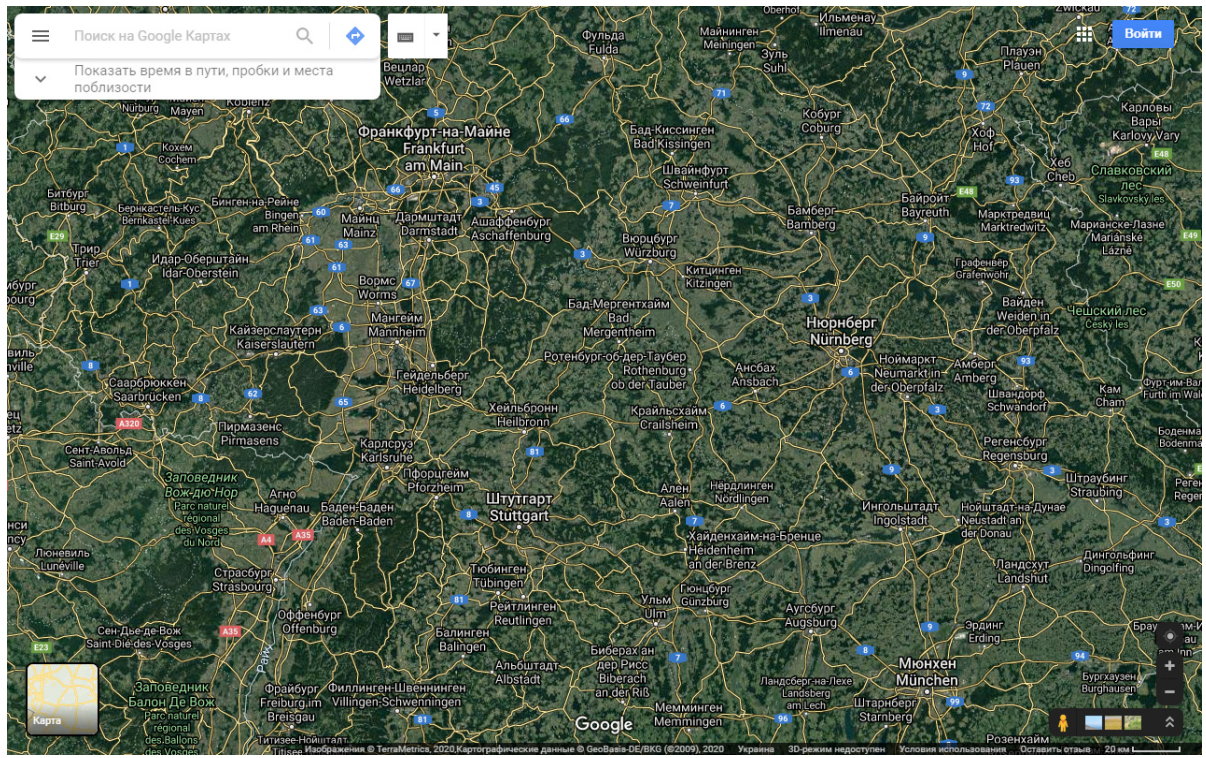

Fig. 4. Representation of the Germany autobahns network using Google images

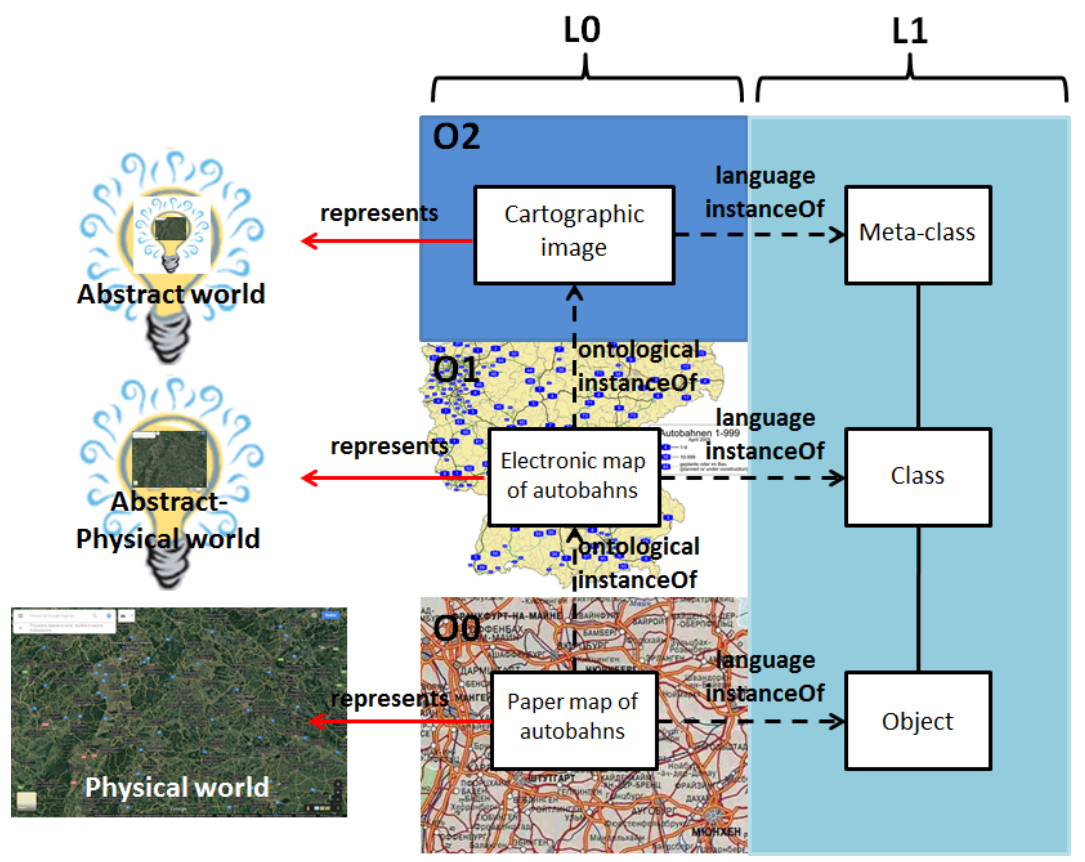

Fig. 5. Clarification of the left and middle parts of Fig. 1

Again, at the end of the section, we note that the described discussion is impossible at all, if the subject of cognition (research) of cartography to leave the maps. The inquiry domain of modern atlases, including the subject of cognition (research) of cartography, changes de facto if their most important critical systemic property will be fulfilled: CSP1.System. The SEA must model actual Spatial systems (SpS). However, there is a question about the practical 
implementation of this CSP. Therefore, we further consider two more critical systemic properties: CSP2.Tree and CSP3.View. These CSP are correlated with the relational and subject properties of atlases as systems.

\section{RELATIONS BETWEEN SOLUTIONS/CONTENTS TREES IN ATLASSF: CSP2.TREE}

In the main sections of Part 1, the "systematic collection", "systematized set", "simple atlas system", "real atlas system" terms were used to denote certain "systemic" subjects. The concepts corresponding to these terms and denoted subjects were formally or informally defined there. All these subjects can be obtained by performing "systematization", which is defined in the Cambridge dictionary as "the act of planning a system for something or organizing something into a system: (such as) the systematization of a set of ideas" [20]. Since the term "system" is not defined here, from the cited definition it is possible to draw a conclusion about its applicability to the "systemic" subjects listed here.

However, to find practically useful CSP we need to understand better the essence of systematization. To do this, we use a more detailed definition from [21; p. 259] : "Systematization" (from the greek systema - a whole consisting of parts) is defined as "mental activity in which the studied objects are organized into a certain system based on the selected principle. The most important kind of S. is classification, that is, the distribution of objects into groups on the basis of establishing similarity and differences between them (for example, the classification of animals, plants, and chemical elements). To S. leads also the establishment of causal relations between the facts under study (for example, in the course of history) and the allocation of the main units of material, which allows considering a specific object as part of the whole system. S. is preceded by analysis, synthesis, generalization, and comparison".

This definition clarifies the meaning of the phrase "systematic collection of maps" from the K. Salishchev's atlas definition. We see that to obtain this "collection of maps" you need to perform systematization, the most important kind of which is the classification. In addition, according to Philosophical encyclopedic dictionary [22] "Systematics (from the Greek sistematikos — ordered) - the science and art of systematization. Systematic - set out in the form of a certain system, which forms a certain system" [23].

In the work [24], we considered the systematics of atlas basemaps in Web 2.0 epoch. There we used the following definition: "Systematics (from the Greek $\sigma v \sigma \tau \eta \mu \alpha \tau \iota \kappa o ́ \varsigma$ — ordered, relating to the system) — bringing into the system, as well as a systemic classification of the study subject. Often, systematics is an auxiliary discipline that helps to organize the objects studied by this science; for example, biological systematics, language systematics" [25]. For us, the most useful is the following explanation from the article "Systematics" of Yu.V. Tchaikovsky [26; Vol. III: pp. 557-558]:

"Systematics - the doctrine of the principles and methods of ordering sets of objects that have essential similarities (systematics of stars, systematics of chemical elements, systematics of animals etc.). The objects of systematics are individuals and their groups. The group legalized in this system is called a taxon and is itself an object of the system. According to K. Behr (1822), the taxon is defined not by boundaries, but by the nucleus of typical forms; this principle was put into practice by W. Wawell (1840), who put forward the thesis 'Class is given precisely, though 
not clearly limited'. Tasks of systematics: 1) classification (description of objects in terms of their essential similarities and differences), 2) nomenclature (assigning a name to each object of the system), 3) definition (finding the name of the object on the presented individual), 4) addressing (finding the object by its name). A system that solves the problem of classification is called natural, and a system that does not pose such a problem is called artificial. The main principles of organization: (1) row (address is an alphabetical order or number), (2) table (address - row and column numbers, if the table is two-dimensional), (3) map (address - coordinates), (4) hierarchy, is graphically expressed by a tree (address - a list of branching points, starting from the top of the tree, indicating the number of the branch at each such point). One set can be arranged in several ways: so, a chemical element can be specified by its number and the intersection of a row of the Periodic Table with a column (both techniques are natural), house - by its coordinates, and hierarchically (postal address). According to S.V. Meyen (1978), systematics - a part of the diversity (diatropics) science, complementary morphology (the doctrine of the plan of structure, common to the objects of the group), and classification is possible due to the natural order of the objects of nature. The principle of classification should be sought, not postulated. On the contrary, it is most convenient to carry out the determination once and for all by the established technique - the dichotomous key (M. Yoreniy, 1710), introduced into the practice by J.-B. Lamarck (1778): if there is a sign, read on, if not, see something there.

CSP2.Tree: DA - Datalogics of solutions tree, DA-DO - Relations between Datalogics of solutions and contents trees, DO - Datalogics of contents tree. It follows from the above that the "ontological classification" may be the first practical CSP. Probably, if the transformations are carried out from an actual spatial system to its "complete" atlas model. The "complete" atlas model for a particular stratum consists of Datologics, Infologics and Organologics (Uselogics). In the graphic images of the atlas model, the transformation is shown to be performed from left to right: actual SpS $\rightarrow$ AtS Datalogics $\rightarrow$ AtS Infologics $\rightarrow$ AtS Uselogics [27]. We name the ontological classification by the Datalogical Epistemological classification. Based on this, the classification of the subject area of each specific atlas should start from top to bottom relative to the graphic images of the strata, in particular, from the Application to the Operational strata. If possible, the Datalogical Epistemological classification for the Conceptual and Application strata should be performed first. Although the classification must be performed from the bottom up, the result of these actions must be a class, not a single instance of that class.

In the Atlas Solutions Framework (AtlasSF) systematics, in the sense of the quoted above Yu.V. Tchaikovsky's article, provides several patterns, including: (A2) solutions/contents tree and (A8) view. In this section, we formulate critical systemic properties only for the (A2) pattern. At once we will notice that in practice we used some of these patterns and all of them are Solutions frameworks. In Web 1.0 Formation, we used three versions of the (A2) pattern, which were components of the corresponding versions of AtlasSF1.0 SoFr, produced every five years since 2000. And in the Web 1.0x1.0 Formation yet one pattern (A2) has been developed and is used so far, which is a component of AtlasSF1.0+ SoFr. From the experience of using AtlasSF1.0 to create about 20 EA/AtIS, we draw the following conclusions: 
- CSP2.Tree.DA - Application Datalogics (DA) of the solutions tree is CSP. It is necessary to start the classification of the subject area for the purpose of further implementation with the Application stratum.

- CSP2.Tree.DA-DO — The rigid relations between Datalogics of solutions and contents trees (DA-DO) is CSP.

- CSP2.Tree.DO - Operational Datalogics (DO) of the contents tree is the CSP. In no case do you need to start the classification of the subject area from the Operational stratum. That is, from the available maps.

We are not able to disassemble CSP2.Tree.DA, CSP2.Tree.DA-DO and CSP2.Tree.DO in detail. Therefore, we present Fig. 6 for explaination what we are talking about. In addition to the already used arguments about the top-down start, you need to use the following simple proof: if there is a CSP2.Tree.DO, then there must be a CSP2.Tree.DA, and without CSP2.Tree. DA-DO it is impossible.

Some static properties of the solutions/contents tree in AtlasSF1.0. In the first Atlas of Ukraine 2000 created by us, the Contents Tree was called the Table Of Contents (TOC). This atlas was also a prototype of EINAU2007/2010 [28], so it can be designated EINAU2000. EINAU2000 TOC was used to navigate the contents and access the content of EA - first EINAU2000, and then several more EA and AtIS in the first half of the first decade of the $21^{\text {st }}$ century. The framework of these solutions was called AtlasSF1.0(1).

From a software viewpoint, TOC implementations on the Operational stratum in the first period (2000-2005) were ActiveX components. Such ActiveX started and supported manipulation of an XML-like .hhc contents file. However, we should not forget about the software system HTML Help Workshop, which allowed to perform the necessary actions on the Application stratum with the component element that was to become the TOC on the Operational stratum. We call this whole componentlex the "solutions tree" for the elements of the Application stratum. The term "table of contents" denotes a set of elements of the Operational stratum.

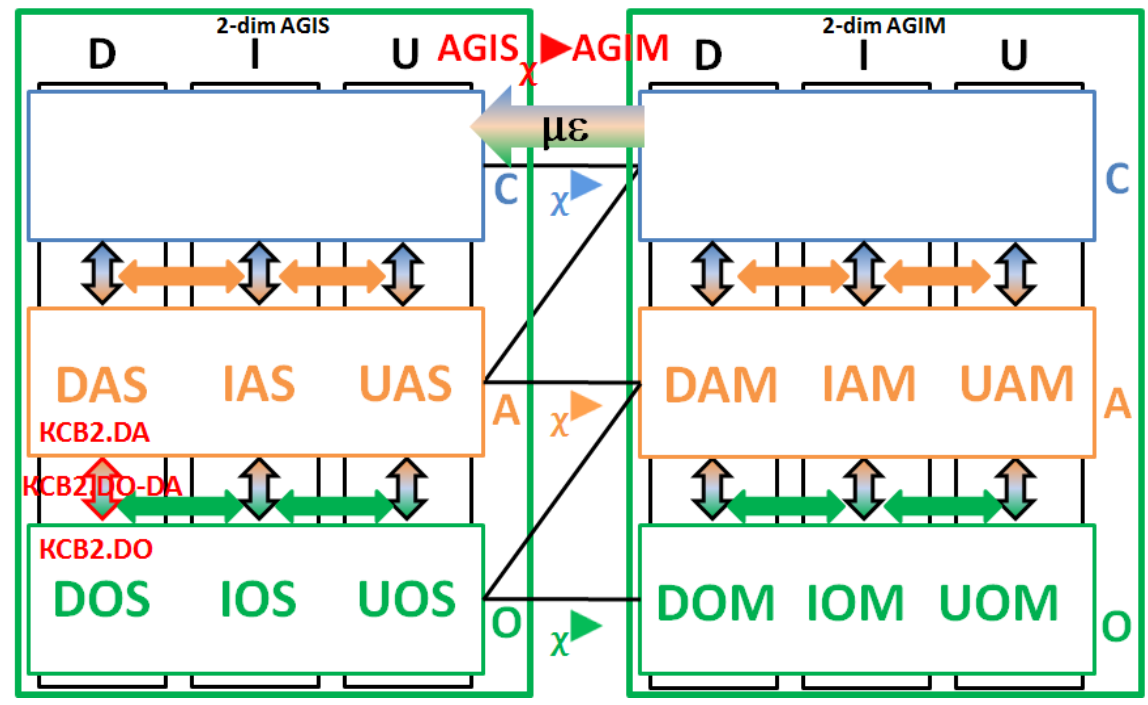

Fig. 6. CSP of the solutions/contents tree in the context of SoFr and CoFr 
In the first decade of this century, EA/AtIS end-user products were produced on optical media and did not allow any changes. After the producing of several EAs/AtIS, it was realized that the solution for this component may be replicated and applied not only in end-user products - in operation, but also earlier — in development — to build the Solutions Tree/Table of Contents that best suits to the end user EA/AtIS. Finally, recent research has shown that this element should be a pattern of the AtlasSF SoFr and is better called the Solutions/contents tree".

HTML Help Workshop was a powerful software system. After its forced replacement by our solution, several of its important properties were lost. In particular, in the updated solutions of edition 2 the ability to search the contents tree was not realized. Although, we repeat that between AtlasSF1.0(1), AtlasSF1.0(2) and AtlasSF1.0(3) there are relations that we call refactoring. However, at the turn of the decade, the 2010 atlas problem arose, which boils down to the fact that now we need to talk not about refactoring, but about reengineering - that is, about a complete rebuild of the solution.

The TOC below are based on the EA/AtIS examples created from 2000 to 2015. The TOC of all these AtS were fixed, immutable components in which the developers reflected the final solutions on structuring the research subject of a particular EA/AtIS on the Operational stratum.

Classification. Table Of Contents (TOC). If we draw an analogy between a paper atlas (PA) published in the form of a book and an Electronic atlas (EA) on $\mathrm{CD} / \mathrm{DVD}$ or on the Internet, in both cases the contents and content of the atlas must be communicated to the user. Usually the Table Of Contents consists of sections, subsections, paragraphs, subparagraphs. In the case of EA, they are branches and/or leaves of the contents tree. By selecting the appropriate item in this tree, the user can gets access to a certain element of EA content - map pages, texts, photo-video materials etc. In contrast to the PA contents in working with the EA contents there are additional advantages: search in the contents, the function "go to the previous/next viewed item/page" and so on.

Fig. 7a shows the contents of EINAU. The Left-Right arrows at the top of the figure implement the "go to the previous/next item/page viewed" function. In the case of a PA, you will need to remember the viewed page or make some bookmarks to repeat this operation is an example of searching for the word "terms" in the contents tree of the Atlas of radioactive contamination of Ukraine (RadAtlas2014, online version). In the PA version, this is almost impossible to implement.

Relations between the elements (components) of the atlas. We should note the relations between the elements (components) of the atlas, which existed since the first activity period of 2000-2005. Fig. 8 illustrates the organization of relations and connections between the elements of RadAtlas2014, although this property was implemented in RadAtlas2002 and in RadAtlas2008. In the table of contents in the left window the letter "Content" leaf is selected. In the right window we have a specific element of the content of the atlas. When you select a map or text, a certain element is loaded, and in the contents tree the cursor moves to the corresponding sheet leaf of the tree. Thus we have a convenient way to "travel" the atlas, using the relationship between its elements.

Dynamic properties of the solutions/contents tree in AtlasSF1.0+. For dynamic Solutions/contents trees of the Web 1.0x1.0 Formation AtS, all critical systemic properties of the Web 1.0 Formation must be met. 


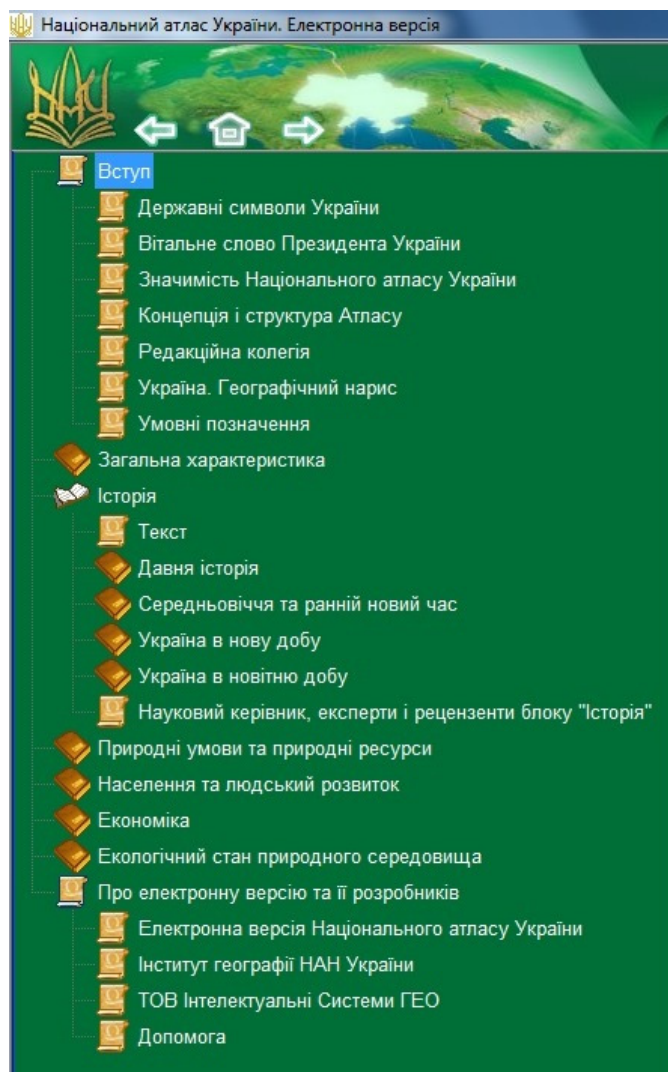

a)

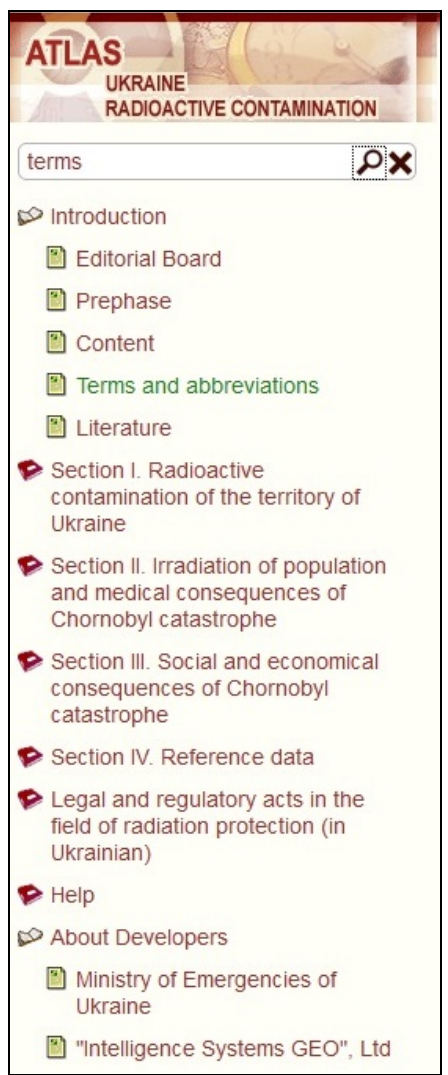

b)

Fig. 7. a) Contents of EINAU, b) Contents of RadAtlas2014 (at the top of TOC — search field)

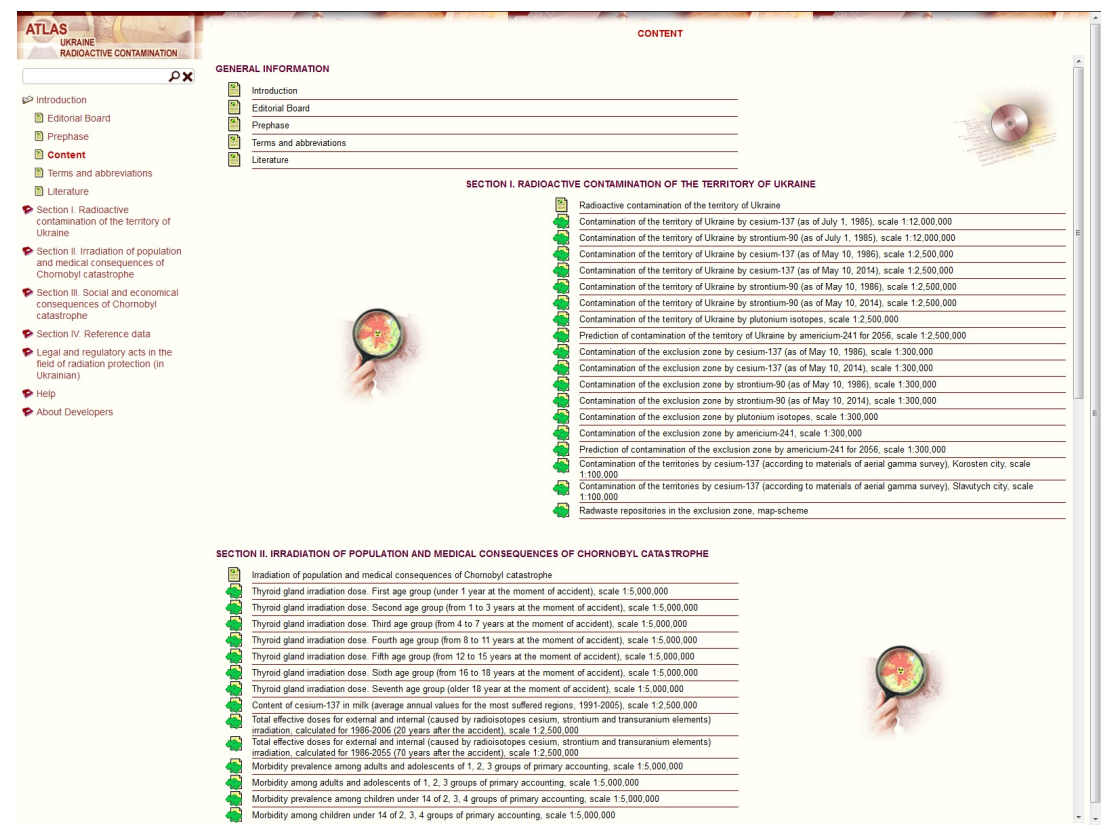

Fig. 8. Organization of relations and links of RadAtlas materials 
Dynamic systemic properties of the pattern (A2) can be divided into two groups: 1) the evolution of static properties, 2) the creation of new properties. They are not called critical, because some of them have not been yet implemented in any of the actual AtS. Below are two examples of such properties.

1. The evolution of static properties is providing dynamics in current versions of the solutions/contents tree SoFr in AtlasSF1.0+. It is based on Mikowski\&apos;s software architecture [29], which is used in the current implementation of AtlasSF1.0+, and on its ability to use external modules. In the case of the main tree, AtlasSF1.0+ uses the jsTree library. Fig. 9 shows the interface of the test version AtlasSF1.0+ (0.0.33), Fig. 10 shows the activation of dynamic changes in the properties of a tree leaf with text. The right mouse button activates the operations Create, Rename, Delete, Edit $>$ Cut, copy, paste. To do this, in the asflplus.toc.js module, a context menu plugin has been added to the jsTree library: plugins: ["search", "contextmenu"]. The search tree plugin implements a local search of (A7) search pattern.

2. The example of new properties creation can be found in the monograph [8]. There are formulated three new patterns for Web 1.0x1.0 Formation AtS: (A9) GeoCollager, (A10) GeoComposer and (A11) GeoRelator. We will not describe now the essence of these new patterns. The simplest of them is GeoCollager, which is already used in the practice of AtS creation. We use an example from the site [30] (Fig. 11).

In the contents tree window (Navigation) on the basemap are selected: 1) UNESCO World Heritage Sites, 2) Monuments of national importance: a) archeology, b) historical, 3) Historical and cultural reserves, 4) Public cadastral map of Ukraine: a) boundaries and numbers of cadastral quarters of urban and land cadastres.

All themes selected in contents tree (Navigation) are displayed at once in the map window (Content). We hope that many people have recognized the displayed territory: it is the central part of Kyiv. The accumulation of monuments in the lower part of the map near Demiivka is explained simply: it is the Baykove cemetery, where there are many immovable monuments of Ukraine.

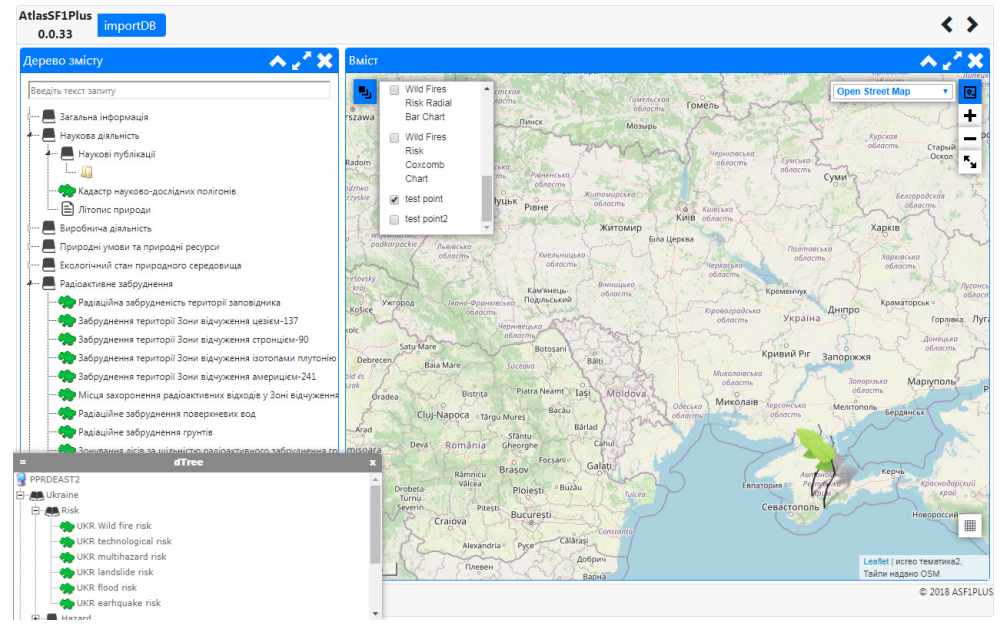

Fig. 9. Test version of AtlasSF1.0+(0.0.33) 


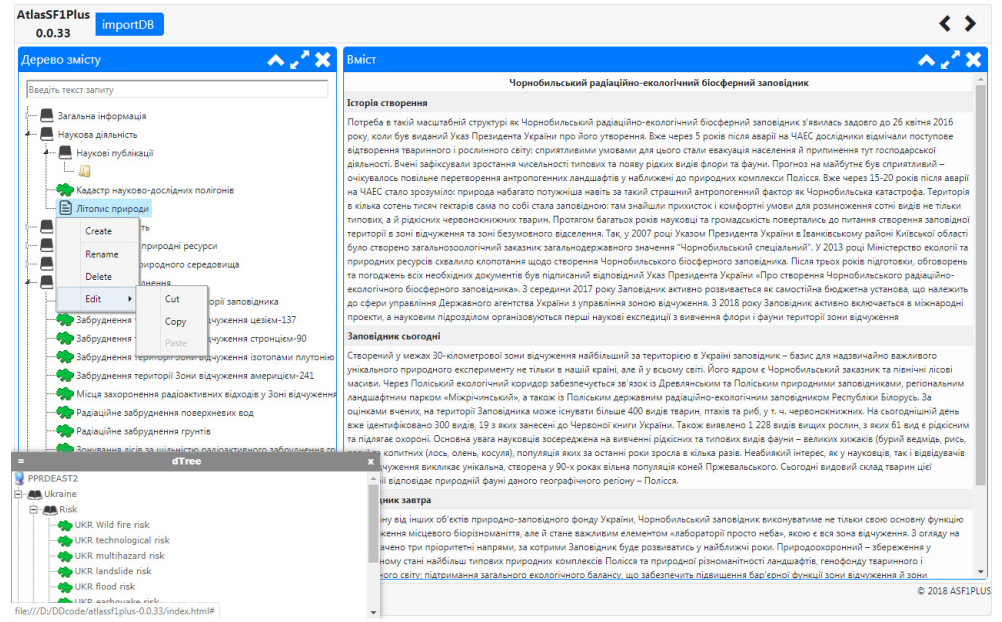

Fig. 10. Dynamic properties of a tree thanks to jsTree

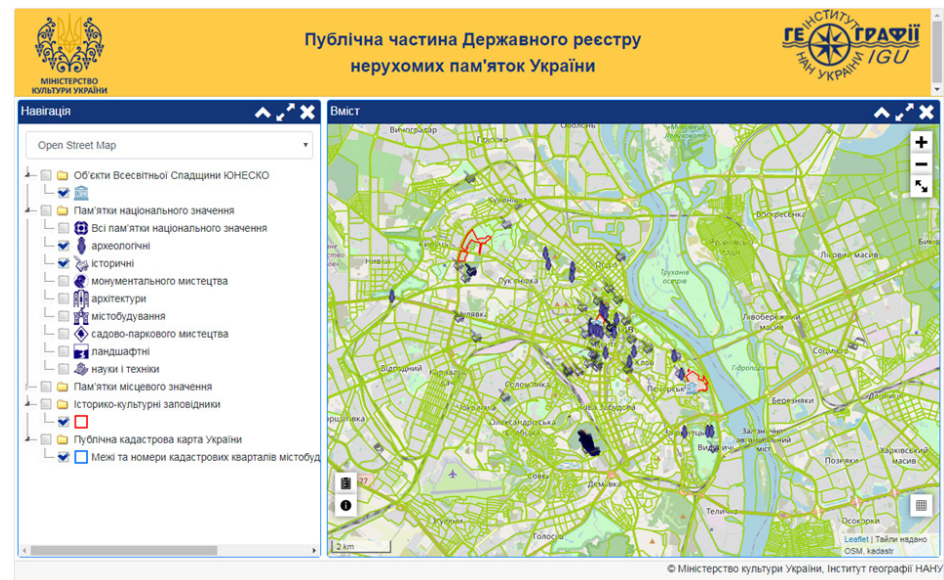

Fig. 11. GeoCollager pattern in the Public register of immovable monuments of Ukraine

We have presented the simplest case of GeoCollager, when there are no relations between the topics. However, we hope that the reader will understand the power of this pattern, provided that we begin to define specific relations between themes.

\section{VIEW PATTERN RELATIONS: CSP3.VIEW}

This section substantiates the CSP3.View (Fig. 12), which we associate with the state (CSP3.View.State) and interactivity (CSP3.View.Interaction) of atlases. CSP3.View is presented in all "old" patterns (A1) - (A8), in "new" patterns (A9) - (A11), as well as in both architectures A0.F1 (Formation Web 1.0) and A0.F1 ${ }^{2}$ (Formation Web $1.0^{2}$ ). Thus first of all it is necessary to address to (A8) View pattern. This pattern is a logical pattern that consists of views of other patterns. View in AtlasSF1.0 was understood by analogy with the *.WOR (workspace) file of MapInfo Professional. In AtlasSF1.0+ this concept was evolved. 
CSP3.View.State explains the following example, which is also related to $\mathrm{SoFr}$ (A2) Solutions/contents tree, (A4) Thematic layers and (A0) Architecture. Through (A0) Architecture communication with the atlas software modules is carried out. This property is understood by all as obvious, but it is often forgotten. Its explanations are shown in Fig. 13 and Fig. 14, which are obtained as follows. First, we displayed the "Migration (urban settlements)" map. To do this, in the tree window we found the name of the map — selected the tree leaf "Migration (urban settlements)" — scaled the map displayed in the map window to the desired scale — opened and placed the drop-down windows "Legend" and "Map Description". This is a description of Fig. 13.

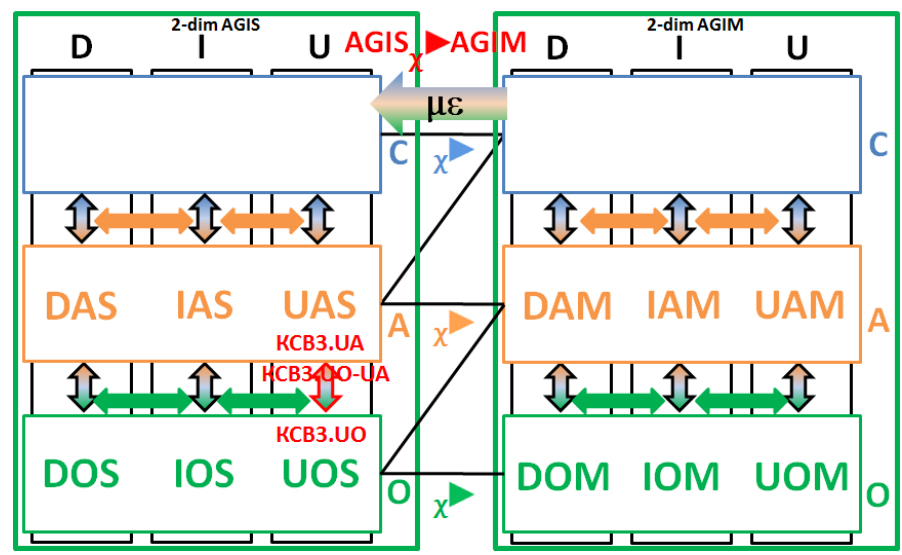

Fig. 12. CSP.View in the context of SoFr and $\mathrm{CoFr}$

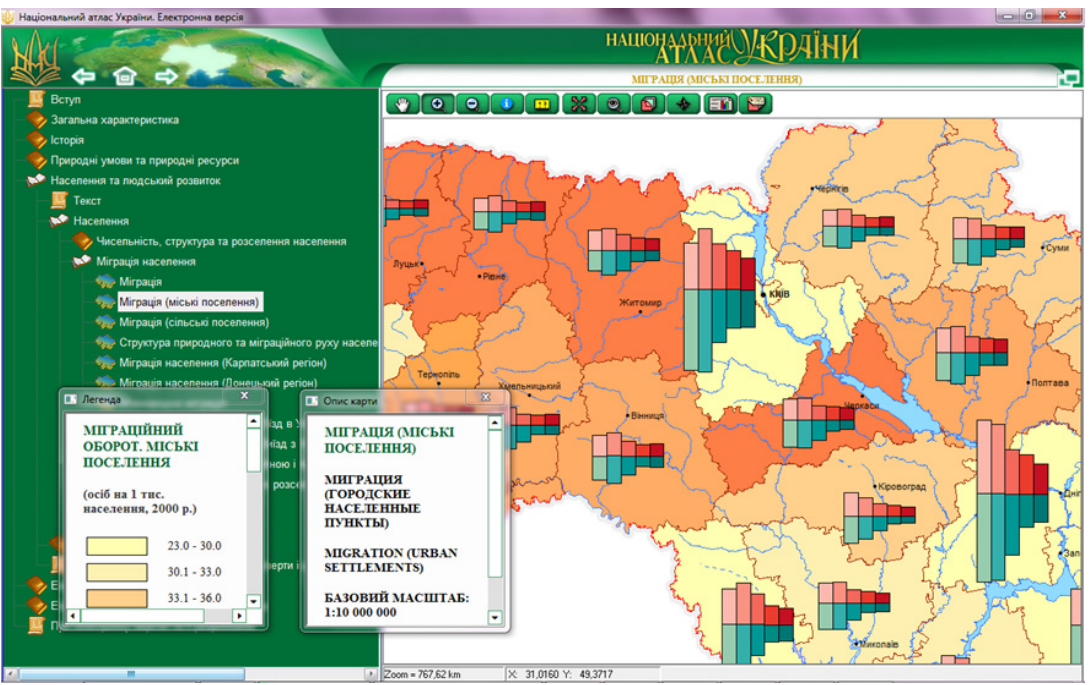

Fig. 13. EINAU2007. Migration (urban settlements) 


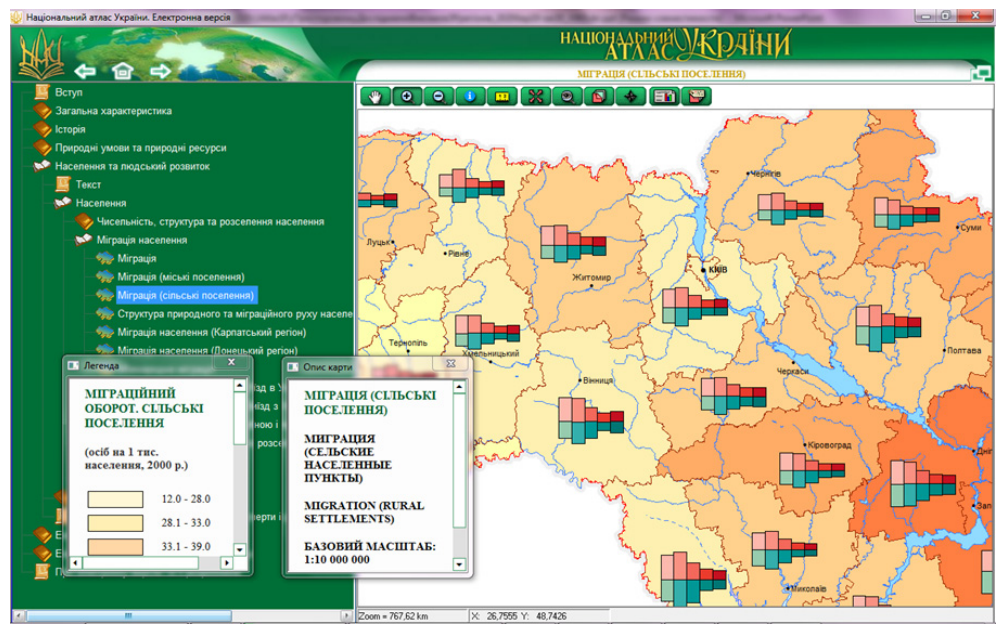

Fig. 14. EINAU2007. Migration (rural settlements)

Then in the tree window we chose a leaf with the name of the "Migration (rural settlements)" map and immediately received the image in Fig. 14. That is, one click got four new images: 1) in the contents tree window a white rectangle highlights the name of the "Migration (rural settlements)" map, 2) in the map window is displayed the "Migration (rural settlements)" map, 3) in the drop-down window "Legend" is reflected the "Migration turnover. Rural settlements" legend, 4) in the drop-down window "Map description" the description of the "Migration (rural settlements)" map is displayed.

The described critical property refers to the (A8) View pattern (SoFr). It is clearly systemic. We formulate it as follows:

- CSP3.View.State. Saving the state of the atlas in the operation session.

CSP3.View.Interaction. In the work [27] we proved that in modern atlas conditions the usual notion of cartographic interactivity should be extended to a certain systemic notion. In this systemic notion of interactivity it is necessary to consider the interactivity of the elements of Operational, Application and Conceptual strata, as well as the relations between them. If we consider the user echelons related to strata, it has been shown that cartographic interactivity cannot be considered in relation to a single user group, fixed, static, single map. On the contrary, it is necessary to consider interactivity for several maps, organized according to existing knowledge and targeted at different user groups. The minimum set of interactivity of such maps should include the interactivity of three dynamically changing maps: operational, application, conceptual.

This set should be consistent with the interactivity of the three $O$ considered by R. Roth [31], [32] in the context of three approaches to interactivity: (1) based on objectives (Objective (first $O$ ) - at the stage of Forming the Intention), (2) based on operators (Operator (second $O$ ) — at the stage of Specifying an Action) and (3) based on operands (Operand (third $O$ ) — at the stage of execution and evaluation, between the stages of Executing the Action and Perceiving the State of the System). For example, when using an operand-based approach (third $O$ ), the focus is on the operand or the digital/virtual object with which the (end) user interacts. When creating a future user interface, the developer must ensure proper feedback regarding changes to the operand (third $O$ ) depending on the operator execution results (second $O$ ). 
R. Roth in his doctoral dissertation [31] describes "cartographic interactivity" as a dialogue between a person and a map, performed using a computer device and understands it as a supplement to the cartographic representation. This fairly general interpretation allows us to consider many aspects of cartographic interactivity that arise in makingand using interactive maps. In particular, R. Roth [31], [32] argues that cartography is in another crisis ("identity crisis" in origin), named by us the "2010 cartography crisis". He suggests a way out of this crisis, which is to use the so-called "Growth perspective". R. Roth [31; Fig. 1.4] believes that all major cartographic paradigms can be included in the Growth perspective. It is depicted as a square with sides (bottom clockwise): cartographic interactivity - making maps cartographic representation - using maps (Fig. 15).
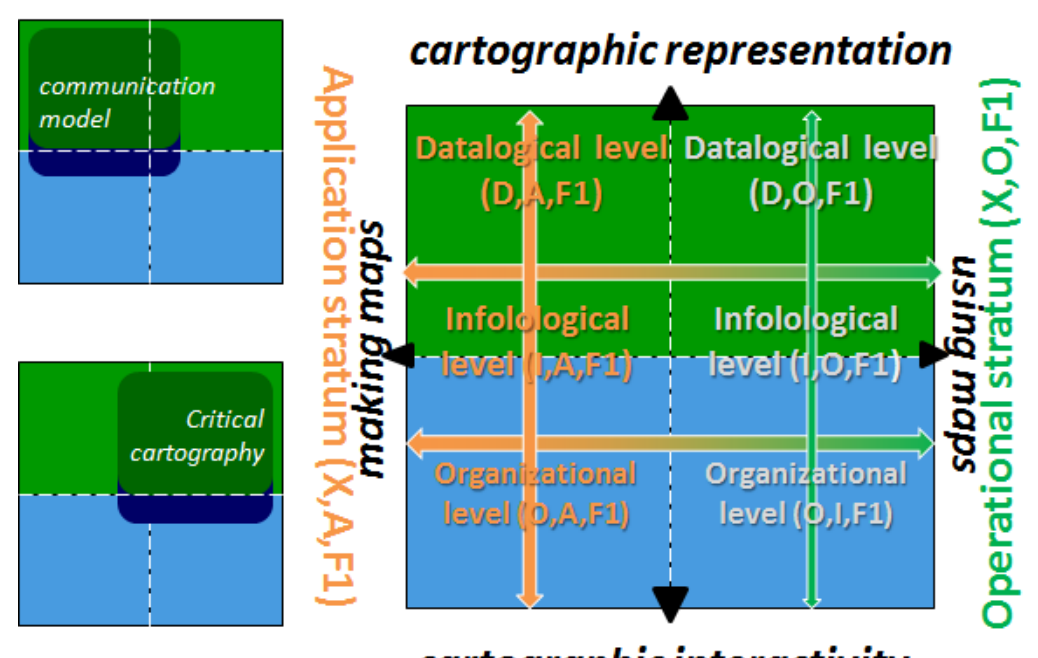

\section{cartographic interactivity}
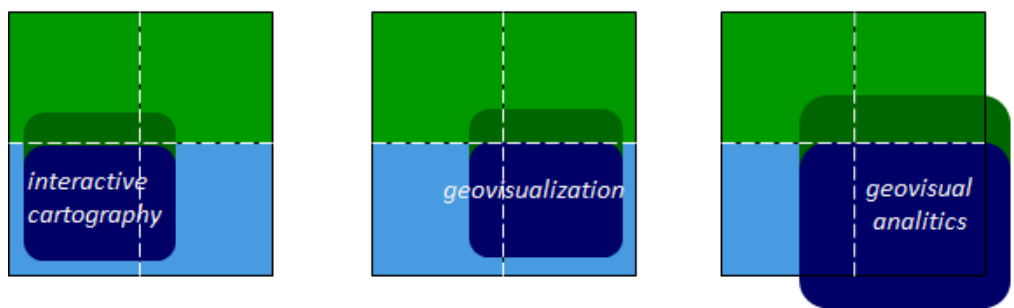

Fig. 15. Relationship of the R. Roth's Growth perspective with the Operational and Application strata of AtS CoFr 
Tabl. 1. Navigation menu of the prototype library of web mapping patterns, which organizes the existing design patterns by sections: "start work", "data", "map elements", "view", "interactivity" [34; p. 124]. The line of designations D, I, U and EINAU column are added by us

\begin{tabular}{|c|c|c|c|c|}
\hline \multicolumn{2}{|c|}{ D } & \multirow[b]{2}{*}{ view } & \multicolumn{2}{|l|}{$\mathbf{U}$} \\
\hline start work & data & & interactivity & $E \boldsymbol{E} \boldsymbol{N} \boldsymbol{A} U$ \\
\hline $\begin{array}{l}\text { template } \\
\text { code } \\
\text { page }\end{array}$ & $\begin{array}{l}\text { data } \\
\text { download }\end{array}$ & tile base map & moving (pan) & \\
\hline & storage & vector base map & $\begin{array}{l}\text { zoom (decrease, } \\
\text { increase) }\end{array}$ & $\oplus$ \\
\hline & export & choropleth & extraction & i) \\
\hline & map elements & proportional symbol & $\begin{array}{l}\text { overlay/switching } \\
\text { (toggle) }\end{array}$ & 成 \\
\hline & $\begin{array}{l}\text { cartographic } \\
\text { grid }\end{array}$ & density of points & filter & (2) \\
\hline & legend & isoline/surface & ordering (arrange) & एवि \\
\hline & & flow & reexpress & $\Leftrightarrow$ \\
\hline & & cartogram & sequence & -+ \\
\hline & & bivariate/ multivariate & resymbolization & + \\
\hline & & animation & redesign & - \\
\hline & & graph/diagram & search & (9) \\
\hline & & & calculation & $\sqrt{12,12}$ \\
\hline
\end{tabular}

In work [33], we showed the relations between the web mapping patterns library of R. Roth's student - Richard Donohue [34] — and the constructions of Relational cartography [8]. In particular, we worked with the original table from [34; p. 124] and obtained Tabl. 1. The symbols of columns "D", "I" and "U" added by us show the correspondence between the columns of R. Donahue\&apos;s table and the levels of AtS CoFr. In blue, we usually denote elements of the Conceptual stratum. This is a correct action, because R. Donahue created a table of design patterns painted in blue, which in [8] are also called conceptual patterns. The patterns of the application stratum are called application, and the patterns of the Operational stratum are called operational. In the work [33] the column of EINAU was also painted blue. There we described the correspondence between the interactivity operands implemented in EINAU and the design patterns of R. Donahue from the column "interactivity".

It would be more correct to describe the design patterns that were implemented in the operands of EINAU (or operational patterns AtlasSF1.0(2)), and then compare the elements of the same epistemological stratum. However, such an action would lead to an unnecessary increase in the volume of the article and would not provide fundamentally new knowledge. With this in mind, we left a line of symbols D, I, U and the column ElNAU in Tabl. 1 unpainted.

We have repeated the evidence that map interactivity in Formation Web $1.0+$ is systemic. This systemic property is also critical, because without it is impossible to develop modern AtSs. It follows from the above material that the interactivity of the maps refers to the presentation of the results of computer-human interaction to the user of the maps. Finally, the presentation of 
maps is a logical part of the presentation of AtS to the user. Therefore, this CSP can be called as follows:

- CSP3.View.Interaction. Interactive presentation of modern AtS to users with different qualifications.

\section{CONCLUSIONS}

The work considers not the subject, but the systemic and relational properties of modern AtS. Subject properties are reduced to the properties of the maps included in the AtS. Electronic atlases (EA) and Atlas information systems (AtIS) were perceived (understood) mainly because of these properties before and, unfortunately, are perceived nowadays.

Relational properties are orthogonal to subject properties. Together they form systemic properties. Relational properties do not depend on the subject, so if we fix the latter, we will again have systemic properties, which here are called systemic-relational. For the purposes of the work, only three CSPs were selected, which belong to two types: purely systemic (CSP1.System) and systemic-relational (CSP2.Tree and CSP3.View). The systemic properties of AtS are nowadays such an urgent problem that now it is appropriate to talk even about critical systemic properties (CSP), without which it is impossible to talk about AtS as a system.

Purely systemic properties include the representation of AtS as a system of some SpIS class - CSP1.System. Representation of AtS as SpIS is a fundamental issue in the field of research of such a science as cartography. Unfortunately, the field of cartography research still remains such subjects as maps. At the same time, such cartographic works as atlases in all previous years belonged to the field of cartography research. Therefore, the contradictions in the definition of cartography are quite obvious, to the field of research of which either EA (and AtIS) belong or do not belong. At the moment, it makes no sense to say that there is another science, the field of research of which includes the field of research of Electronic atlases and Atlas information systems. GIScience immediately comes to mind, although this is just the name of the undertheory may be paradigm. This and other paradigms, despite the names, are not yet theories, so the corresponding sciences should be considered with some clarification of the name - for example, "applied".

Systemic-relational properties include such critical properties as "tree" and "view". The "tree" consists of trees of contents and solutions and the relations between them. The main property of the contents tree and the solutions tree is their ability to implement the classification relations in the sense of the article [2]: ontological and possibly language (linguistic, both epistemological). Classification is not only a relation, but also, perhaps, the most famous method of research and design of systems. CSP2.Tree systemic-relational critical property is related to a CSP1.System purely systemic property. This CSP does not say anything about subjects - maps.

"View" systemic-relational property consists of the AtS state as a system at a given time moment and of the relations between these states. The state of the system (CSP3.View.State) is a representation of AtS for the end user at a given time. From the end user\&apos;s viewpoint, changes between system states occur 
by performing interactivity operands. Atlas interactivity is a combination of the interactivity of its main components. The essential AtS components are the maps included in the AtS, as well as their interactivity. The work [27] proves the correspondence between the constructions of Relational cartography and the constructions of interactivity of the new paradigm of cartography, which its author R. Roth called the (cartographic) Growth perspective paradigm. One of the important properties of this paradigm is its basis. According to [31], this basis, in addition to cartographic interactivity, includes the main actual in 2010 paradigms of cartography.

\section{REFERENCES}

1. Chabaniuk V., Kolimasov I., Krakovskyi S. Critical systemic properties of Electronic atlases new generation. Part 1: Problem and research methods. Cybernetics and Computer Engineering. 2021, № 2(204), pp. 20-49.

2. Kühne Thomas. Matters of (meta-)modeling. Softw. Syst. Modeling. 5, 2006, pp. 369-385.

3. Chabaniuk V., Polyvach K. Critical properties of modern geographic information systems for territory management. Cybernetics and Computer Engineering. 2020, № 3(201), pp. 5-32.

4. Klir G.J. Architecture of Systems Problem Solving. New York: Springer, 1985.

5. Gaines Brian R. General systems research: quo vadis? General Systems: Yearbook of the Society for General Systems Research. 1979, Vol. 24, pp. 1-9.

6. Cresswell Tim. Geographic Thought: A Critical Introduction (Critical Introductions to Geography). Wiley-Blackwell, 2013. 298 p. (290 (300) p.)

7. Aslanikashvili A.F. Metacartography. Main problems. Tbilisi: Metsniereba, 1974. 126 p. (in Russian)

8. Chabaniuk Viktor. Relational cartography: Theory and practice. Kyiv: Institute of Geography of the NAS of Ukraine, 2018, 525 p. (in Ukrainian)

9. URL: https://icaci.org/mission/ [Last accessed 10.07.2021].

10. Brambilla Marco, Cabot Jordi, Wimmer Manuel. Model-driven Software Engineering in Practice (Synthesis Lectures on Software Engineering). Morgan \& Claypool Publishers, $2^{\text {nd }}$ Ed., 2017, 209 p.

11. Dictionary by Merriam-Webster, https://www.merriam-webster.com/ [Last accessed 17.09.2021]

12. URL:https://www.weltkarte.com/europa/landkarten-und-stadtplaene-vondeutschland/landkarte- deutschland-autobahnnetz.htm [Last accessed 10.07.2021].

13. URL:http://www.autobahntourismus.de/ [Last accessed 10.07.2021].

14. URL:https://ru.wikipedia.org/wiki/Автомагистрали_Германии [Last accessed 10.07.2021].

15. URL:https://www.google.com.ua/maps/@49.3402178,9.6836355,8z?hl=ru [Last accessed 10.07.2021].

16. Salichtchev K.A., Ed. Complex Regional Atlases. M.: MSU Publishing, 1976, 638 p. (in Russian)

17. Salichtchev K.A. Cartography. Textbook. M.: MSU Publishing, $1990,3^{\text {rd }}$ Ed, 400 p. (in Russian)

18. Svatkova T.G. Atlas cartography. Textbook. M.: Aspect Press, 2002, 203 (210) p. (in Russian)

19. URL:https://www.google.com.ua/maps/@49.3402178,9.6836355,258690m/data=!3m1!1e3?hl=ru [Last accessed 10.07.2021].

20. URL: https://dictionary.cambridge.org/ru/словарь/английский/systematization [Last accessed 27.08.2020].

21. Pedagogical Encyclopedic Dictionary. / Ch. ed. B.M. Bim-Bad. M., Large Russian Encyclopedia, 2002, 528 p. [Last accessed 30.04.2021], URL: https://pedagogical_dictionary.academic.ru/2945/Систематизация 
22. Philosophical encyclopedic dictionary, 2010. [Last accessed 11.07.2021], URL: http://philosophy.niv.ru/doc/dictionary/philosophy/index.htm.

23. URL: http://philosophy.niv.ru/doc/dictionary/philosophy/fc/slovar-209-2.htm\#zag-2490 [Last accessed 10.07.2021].

24. Chabaniuk V., Dyshlyk O. Atlas Basemaps in Web 2.0 Epoch. The International Archives of the Photogrammetry, Remote Sensing and Spatial Information Sciences, V. XLI-B4, 2016 XXIII ISPRS Congress, (12-19 July 2016, Prague), Prague, Czech Republic, pp. 611-618.

25. URL: https://uk.wikipedia.org/wiki/Систематика [Last accessed 03.07.2021].

26. New Philosophical Encyclopedia: In 4 volumes / Institute of Philosophy RAS, Nat. general scientific fund; Scientific ed. Council: Chairman V.S. Stepin, Deputy Chairmens: A.A. Guseinov, G.Yu. Semigin, Scientific Secretary A.P. Ogurtsov. M.: Thought, 2010. ISBN 978-2-244-01115-9. V. I. 2010. 744 p. ISBN 978-2-244-01116-6. V. II. 2010. 634, [2] p. ISBN 978-2-244-01117-3. V. III. 2010. 692, [2] p. ISBN 978-2244-01118-0. V. IV. 2010. 736 p. ISBN 978-2-244-01119-7. (in Russian)

27. Chabaniuk V.S, Rudenko L.G. Software solutions in the processes of creating and using atlas interactive maps. Journal of the Belarusian State University. Geography. Geology. 2019, No. 2, pp. 25-39. Russian. https://doi.org/10.33581/2521-6740-2019-2-25-39

28. Bochkovska, et al. Electronic version of the Pilot Project "The National Atlas of Ukraine”. Ukrainian Geographic Journal, 2000, № 1, pp. 48-61 (in Ukrainian)

29. Mikowski Michael, Powell Josh. Single Page Web Applications: JavaScript end-to-end.Manning Publications. 2014, 407 (433) p.

30. URL: http://publicregistry.heritage.in.ua/ [Last accessed 07.07.2020].

31. Roth Robert E. Interacting with Maps: The science and practice of cartographic interaction. The Pennsylvania State University, Doctor of Philosophy (Geography) Dissertation, 2011.215 (225) p. DOI: 10.1179/1743277412Y.0000000019.

32. Roth Robert E. Interactive Maps: What We Know And What We Need To Know. Journal of Spatial Information Science. No. 6, 2013, pp. 59-115. DOI: 10.5311/JOSIS.2013.6.105.

33. Interactive maps: essence and software solutions for creation and use, pp. 21-35, in Rudenko L., ed. Actual directions of cartography development in Ukraine. Kyiv, Institute of Geography of the National Academy of Sciences of Ukraine, 2019. 88 p. (in Ukrainian)

34. Donohue Richard G. Web Cartography with Web Standards: Teaching, Learning, and Using Open Source Web Mapping Technologies. University of Wisconsin-Madison, Doctor of Philosophy (Geography) Dissertation, 2014, 167 (173) p.

Received 22.03.2021

\section{ЛІТЕРАТУРА}

1. Chabaniuk V., Kolimasov I., Krakovskyi S. Critical systemic properties of Electronic atlases new generation. Part 1: Problem and research methods. Cybernetics and Computer Engineering, 2021, № 2(204), pp. 20-49.

2. Kühne Thomas. Matters of (meta-)modeling. Softw. Syst. Modeling, 2006, 5, pp. 369-385.

3. Chabaniuk V., Polyvach K. Critical properties of modern geographic information systems for territory management. Cybernetics and Computer Engineering, 2020, № 3(201), pp. 5-32.

4. Klir G.J. Architecture of Systems Problem Solving. New York: Springer, 1985.

5. Gaines Brian R. General systems research: quo vadis? General Systems: Yearbook of the Society for General Systems Research, Vol. 24, 1979, pp. 1-9.

6. Cresswell Tim. Geographic Thought: A Critical Introduction (Critical Introductions to Geography). Wiley-Blackwell, 2013. 298 p. (290 (300) p.)

7. Асланикашвили А.Ф. Метакартография. Основные проблемы. Тбилиси: Мецниереба, 1974. $126 \mathrm{c}$.

8. Чабанюк В.С. Реляційна картографія: Теорія та практика. Київ: Інститут географії НАН України, 2018. 525 с.

9. https://icaci.org/mission/, accessed 2021-jul-10. 
10. Brambilla Marco, Cabot Jordi, Wimmer Manuel. Model-driven Software Engineering in Practice (Synthesis Lectures on Software Engineering).- Morgan \& Claypool Publishers, $2^{\text {nd }}$ Ed., 2017. 209 p.

11. Большой Энциклопедический Словарь. Гл. редактор Прохоров А.М. Советская Энциклопедия, 1993. 1628 с.

12. https://www.weltkarte.com/europa/landkarten-und-stadtplaene-vondeutschland/landkarte- deutschland-autobahnnetz.htm, accessed 2021-jul-10.

13. http://www.autobahntourismus.de/, accessed 2021-jul-10.

14. https://ru.wikipedia.org/wiki/Автомагистрали_Германии, accessed 2021-jul-10.

15. https://www.google.com.ua/maps/@49.3402178,9.6836355,8z?hl=ru, accessed 2021-jul-10.

16. Салищев К.А., ред. Комплексные региональные атласы. М.: Изд-во МГУ, 1976. 638 с.

17. Салищев К.А. Картоведение. Учебник. М.: Изд-во МГУ, 1990, 3-е изд. 400 с.

18. Сваткова Т.Г. Атласная картография. Учебное пособие. М.: Аспект Пресс, 2002. 203 (210) c.

19. https://www.google.com.ua/maps/@49.3402178,9.6836355,258690m/data=!3m1!1e3?hl=ru, accessed 2021-jul-10.

20. https://dictionary.cambridge.org/ru/словарь/английский/systematization, accessed 2020-aug-27

21. Педагогический энциклопедический словарь. / Гл. ред. Б.М. Бим-Бад. М., Большая российская энциклопедия, 2002. 528 с. Доступ 2021-июл-10, https://pedagogical_dictionary.academic.ru/2945/Систематизация)

22. Философский энциклопедический словарь, 2010.- Доступ 2021-июл-10, http://philosophy.niv.ru/doc/dictionary/philosophy/index.htm.

23. http://philosophy.niv.ru/doc/dictionary/philosophy/fc/slovar-209-2.htm\#zag-2490, accessed 2021-jul-10.

24. Chabaniuk V., Dyshlyk O. Atlas Basemaps in Web 2.0 Epoch. The International Archives of the Photogrammetry, Remote Sensing and Spatial Information Sciences, V. XLI-B4, 2016 XXIII ISPRS Congress, 12-19 July 2016, Prague, Czech Republic, pp. 611-618.

25. https://uk.wikipedia.org/wiki/Систематика, accessed 2020-jul-03.

26. Новая философская энциклопедия: В 4 т./Ин-т философии РАН, Нац. общ.-научн. фонд; Научно-ред. совет: предс. В.С. Степин, заместители предс.: А.А. Гусейнов, Г.Ю. Семигин, уч. секр. А.П. Огурцов. М.: Мысль, 2010.-ISBN 978-2-244-01115-9. Т. I. 2010. 744 с.ISBN 978-2-244-01116-6. T. II. 2010. 634, [2] c. - ISBN 978-2-244-01117-3. T. III. 2010. 692, [2] c.- ISBN 978-2-244-01118-0. T. IV. 2010. 736 c. - ISBN 978-2-244-01119-7.

27. Чабанюк В.С., Руденко Л.Г. Программные решения в процессах создания и использования атласных интерактивных карт. Журнал Белорусского государственного университета. География. Геология, 2019, No. 2, с. 25-39. https://doi.org/10.33581/2521-6740-2019-2-25-39

28. Бочковська, та ін. Електронна версія пілотного проекту «Національний атлас України». Украӥнський географічний журнал, 2000, № 1, с. 48-61.

29. Mikowski Michael, Powell Josh. Single Page Web Applications: JavaScript end-to-end.Manning Publications, 2014. 407 (433) p.

30. http://publicregistry.heritage.in.ua/, access 2020-jul-07

31. Roth Robert E. Interacting with Maps: The science and practice of cartographic interaction. The Pennsylvania State University, Doctor of Philosophy (Geography) Dissertation, 2011. 215 (225) p. DOI: 10.1179/1743277412Y.0000000019.

32. Roth Robert E. Interactive Maps: What We Know And What We Need To Know. Journal of Spatial Information Science, No. 6, 2013, pp. 59-115. DOI: 10.5311/JOSIS.2013.6.105.

33. Інтерактивні карти: сутність та програмні рішення при створенні та використанні, c. 21-35 // Руденко Л., ред. Актуальні напрямки розвитку картографії в Україні. Київ, Інститут географії НАН України, 2019. 88 с.

34. Donohue Richard G. Web Cartography with Web Standards: Teaching, Learning, and Using Open Source Web Mapping Technologies. University of Wisconsin-Madison, Doctor of Philosophy (Geography) Dissertation, 2014. 167 (173) p.

Отримано 22.03.2021 
Чабанюк В.C. ${ }^{1,2}$, канд. фіз.-мат. наук, старш. наук. співроб. відд. картографії Інституту географії НАН України, директор ТОВ «Інтелектуальні системи-ГЕО»,

ORCID: 0000-0002-4731-7895

e-mail: chab3@i.ua,chab@isgeo.kiev.ua.

Колімасов I.M. ${ }^{2}$,

начальник виробництва ТОВ "Інтелектуальні системи-ГЕО",

ORCID: 0000-0002-4927-4200

e-mail: kolimasov@ukr.net,van@isgeo.kiev.ua.

${ }^{1}$ Інститут географії НАН України,

вул. Володимирська, 44, м. Київ, 01030, Україна

${ }^{2}$ ТОВ «Інтелектуальні системи-ГЕО»,

вул. Микільсько-Слобідська, 6/44, м. Київ, 02002,Україна

КРИТИЧНІ СИСТЕМНІ ВЛАСТИВОСТІ ЕЛЕКТРОННИХ АТЛАСІВ НОВОГО ПОКОЛІННЯ. ЧАСТИНА 2: РЕЗУЛЬТАТИ ДОСЛІДЖЕННЯ

Вступ. У Частині 2 розглядаються три критичні системні властивості (КСВ) Електронних атласів (ЕА) нового покоління. За допомогою цих КСВ визначаються принципово нові, системні ЕА. Порівняно з класичними, системні ЕА мають набагато більше можливостей моделювати просторові системи дійсності.

Метою статті $є$ опис і доведення критичності трьох КСВ для нового покоління ЕА системних ЕА.

Результати. Описано три КСВ: КСВ1.Система, КСВ2.Дерево, КСВ3.Подання. КСВ1.Система означає, що системні ЕА повинні бути моделями просторових систем дійсності. Ці моделі $є$ первинними на відміну від моделей класичних ЕА, які $є$ вторинними. КСВ2.Дерево означає, що дерево змісту/рішення системного ЕА має класифікувати просторову систему дійсності, що моделюється. КСВ3.Подання має моделювати візуалізаційні потреби користувачів, зокрема, за допомогою інтерактивності. Для доведення використано методи Концептуальних каркасів і Каркасів рішень Реляційної картографії, а також факти 3 Базованої на моделях інженерії.

Висновки. Описано три КСВ системних ЕА і доведено, що кожна 3 них $є$ необхідною властивістю ЕА нового покоління.

Ключові слова: Електронні атласи нового покоління, критична системна властивість, Конщептуальний каркас, Каркас рімень, Реляиійна картографія 